\title{
EDUCATIONAL IDEAL IN THE PEDAGOGICAL WORKS OF WESTERN UKRAINE IN THE INTERWAR PERIOD
}

\section{Nevmerzhytska 0 .}

\section{INTRODUCTION}

The interwar period in Western Ukrainian lands (Eastern Galicia, Transcarpathia) is characterized by the formation of civil society, the rise of the national spirit, the development of the national school system. According to the Treaty of Saint-Germain (1919), Volhynia, Eastern Galicia, Chelm Land, Podlachia and Nadsania were under Polish rule. The situation of the Ukrainian lands during this period was ambiguous. On the one hand, Poland declared a course on the development of a democratic society, ensuring the development of national minorities, but on the other, this period was characterized by an aggravation of the national issue and discriminatory actions of the government on the rights of Ukrainians.

Despite the artificial suppression of the economic development of Galician villages, religious pressure and the ban on the activities of individual Ukrainian parties and public cultural and educational organizations, there were several vigorous parties (Prosvita, Native School Pedagogical Society, etc.) and youth societies (Plast, Sokol, Sich, Orly, Luh, etc.), and the system of private national schooling was being actively developed at the time. The expansive actions of the Polish authorities provoked active opposition and development of civil society in Eastern Galicia.

The conditions for the development of civil society in the Transcarpathian lands were even more favorable, since Czechoslovakia was much more democratic than Poland. Its leadership policy, led by Tomáš Masaryk, contributed to the development of political life, the establishment of nearly three dozen political parties that had different, often diametrically opposite views on the social development of the region, 
its economic opportunities, as well as Ukrainian national schooling. Thus, Vira Fedelesh, a teacher of history of the Mukachevo Civic School wrote about this period in a textbook on the history of Subcarpathian Ukraine: the government is carried out in the Slavic spirit. Public schools are Ruthenian and Ruthenian language is studied as a compulsory subject in each one of them. "May our Subcarpathian Ruthenia always be Ruthenian and may the Ruthenian culture flourish in it at all times"1.

The most difficult situation was in Bukovyna. After its occupation by Romania, the process of curtailing its previous achievements took place. Bukovyna's autonomous rights were abolished and it was transformed into the province of Romania. Romanianization of all spheres of life took place in the land: the use of the Ukrainian language was forbidden, the Ukrainian schools, cultural and educational institutions, as well as magazines were shut down. However, even under these difficult circumstances, Ukrainians tried to defend their rights, and the most vivid expression of the national liberation movement was acquired in the activities of the Organization of Ukrainian Nationalists.

The uprising at the site of the dynastic new nation states set the important task of self-reliance and self-affirmation before them, and it could not be achieved without the proper education of citizens before the realization of new state-building tasks. Therefore, the priority of the school's activity was the state-civic education of different content, depending on the political ideologies of the new states to which the school's intellectual and educational goal was subordinated. According to Yakym Yarema, the problem of the school became a matter of national importance. The author has analyzed the ideological underpinnings of the activity of European schools, pointing out that the focus of school-based education has become social-class education and upbringing in Eastern Europe and national education and upbringing in the West. And if social education aims to educate "socially and internationally-minded activists", the national education tries to be "a hotbed of state-national patriot

\footnotetext{
${ }^{1}$ Феделешъ В.И. Учебникъ исторіи Подкарпатской Руси отъ найдавнЂйшихъ временъ до днешнихъ дней и Чехословакіи до XIV. вЂека. Мукачево : Типографія «Карпатія», 1922. С. 32.
} 
activists. There is a spirit of internationalism which, in its essence, is merely an expression of Moscow's national aspirations for power over the world, that took possession of the school; here, multicolored nationalism is pushed into the school, making it, depending on the nation-state, its traditions, historical claims and aspirations, a multifaceted instrument of its great-power politics". Therefore, according to the author, the school has entered a phase of deep state-national differentiation, filling itself with peculiar content and serving different social and political ideologies, ideals and worldviews in each state ${ }^{2}$.

This can be easily traced to the justification of the educational ideal of the Polish (Western Ukrainian lands were part of the Second Commonwealth at the time) and Western Ukrainian educators.

\section{Educational ideal in Polish pedagogy}

At the beginning of the twentieth century, Polish educators substantiated the ideal of an "honest person and a good citizen", which was similar to pan-European expectations, but was based on the opinions, desires, and postulates of the national elite [30]. More broadly, the Polish educational ideal is presented in the writings of Galician teacher Irena Pannenkova. She studied at Lviv University and later worked in secondary schools of Galicia.

According to the educator, the main purpose of education is to prepare a person for the fulfillment of life's tasks mainly as an individual according to the innate forces, needs and abilities (individual education), as the son or daughter of their nation in relation to society (civic education), as a representative of their own era in relation to the rest of humanity (public education) and as an immortal being in relation to God (religious education) $)^{3}$.

In the work "Thoughts On Folk Education" Pannenkova argued that the ideal can be natural or artificial, clearly delineated or inaccurate and blurred. But it is always folk, and so is education. Its tasks are to rely on

\footnotetext{
2 Ярема Я. Нова фаза в розвитку європейської школи. Українська Школа. 1934. Річник ХІХ. С. 3-11.

${ }^{3}$ Pannenkowa I. Nasze zadania wychowawcze. Warszawa, 1929. S. 6.
} 
national character as the natural source and foundation of pedagogical works, to improve people's natural inclinations and to eliminate and smoothen its negative features ${ }^{4}$.

Recognizing that each nation creates an educational ideal according to its peculiarities and needs, Irena Pannenkova tries to identify the basic features of the Polish psyche. She believes that the Polish psyche emphasizes the dependence of the common cause on the individual attitude, and especially on the moral state of each individual. It embodies the desire for freedom and its worship as the highest good on earth ${ }^{5}$. The Polish people are individualistic in nature and universal in their tendency. At the same time, in the Polish soul the most capable of development is the moral side.

When speaking about the Polish ideal of education, a citizen must be brought up with the following basic features: independence and creativity, civic responsibility. The first task of public education should be the development of qualities such as the ability to think independently, the ability to control oneself and moral independence. Appropriate moral and religious culture, capacity for introspection and self-criticism, sober and fair judgments about people and things, cult of tradition, love for truth, honor for true merit, ability for sacrifice and submission, and above all love for the Motherland, to which individual creativity is rooted and to which it is driven, are the traits that give rise to a sense of civic responsibility. An individual who has a healthy body, developed intelligence and unbreakable will becomes a perfect, malleable tool in their own life work, in creative and responsible actions - a human being not only with blood and body, but also with the movement of their soul, the strongest knots of thoughts and feelings united with their land and the people among which they were raised and to which they return with their creativity, devoting their lives to serving for the People, humanity and

\footnotetext{
4 Pannenkowa I. Myśli o wychowaniu narodowem. Lwów : Nakł. «Polskiego T-wa pedagogicznego», 1918. S. 35.

Pannenkowa I. Myśli o wychowaniu narodowem. Lwów : Nakł. «Polskiego T-wa pedagogicznego», 1918. S. 14-19.
} 
God. Such is a complete and individual person, a citizen, and a creator. This is the ideal, this is the purpose of folk education in Poland ${ }^{6}$.

However, when analyzing the situation in Galician schools, the scientist concluded that their deviation from the ideal in public education is simply frightening. Irena Pannenkova gave the following example. Galician school, trained on German models, is burdened with their lethal leveling of the individuality of pupils and overburdening of thinking, on the one hand, and neglect of religious and moral education, as well as levity of physical education as a duty of the school, on the other ${ }^{7}$.

In our opinion, the educational process in Galician schools was slowed down not only by the above-mentioned factors. It should be added that the efforts of the Ukrainian youth to educate the patriots of the Polish state on the models of Polish culture and language significantly complicated and hampered this process. After all, Konstantin Ushinsky wrote that "despite the similarity of the pedagogical forms of all European countries, each of them has its own special national education system, its own special purpose, and its own special means of achieving this goal"8.

The purpose of Polish education described by Irena Pannenkova has a noble character, is aimed at forming a creative, competent personality, an individual who serves the Motherland and God, and is in many respects consistent with the purpose of modern Ukrainian education. But what constitutes the basis of Polish education may not fully serve the formation of Ukrainians, as they have their own natural features, mentality and aspirations, as well as their own path. The inability to be brought up in their native language and on their own national customs, traditions, legends, history and literature hindered the development of Ukrainian children and youth, and therefore did not contribute to the social progress of Galicia.

\footnotetext{
6 Pannenkowa I. Myśli o wychowaniu narodowem. Lwów : Nakł. «Polskiego T-wa pedagogicznego», 1918. S. 38-41.

Pannenkowa I. Myśli o wychowaniu narodowem. Lwów : Nakł. «Polskiego T-wa pedagogicznego», 1918. S. 34.

${ }_{8}$ Ушинський К. Про народність у громадському вихованні. Вибрані педагогічні твори : у 2-х т. К. : Радянська школа, 1983. Т. 1. С. 47.
} 


\section{Ukrainian educational ideal in the heritage of educators of the interwar period}

After World War I, the problem of finding a new Ukrainian educational ideal was also aggravated in Western Ukrainian lands. "In the field of education there is a majestic scientific movement, passionate search for new truths and ideals of education"".

In contrast to the Polish educational ideal, a patriot citizen who believes in God and obeys His commandments, Ukrainian educators have sought to create a Ukrainian educational ideal that, in a stateless Ukraine, would help preserve national identity, promote political, economic and cultural development in Eastern Galicia. Therefore, this ideal was formed taking into account the influences of Western European pedagogy and the needs of the Ukrainian people and consisted in the formation of an educated and honest person, a useful member of society with a strong and healthy body and spirit ${ }^{10}$. The main emphasis was on the harmonious development of all the forces of the child: "The ideal of modern education aims at the uniform development of all the abilities of the child. This uniform development leads to the attainment of the harmonious integrity of an individual"11. This task has arisen in the context of seeking by not only Ukrainian but also Western European educators, who emphasized the priority of education. The school was given a task of educating a person for the needs of life. In this case, education became a means of upbringing and a way of attaining an educational goal.

The idea of educational training in which the national culture plays a major role was developed in the heritage of Galician educators. Since culture is extremely broad, its educational values (religious, moral, social, aesthetic, economic) can be found both in the content of the educational material and in the school life itself ${ }^{12}$. The starting point of education, according to Ivan Velyhorskyi, is the teaching of life on the basis of native culture. "The goal is to create a new type of person on the basis of the

\footnotetext{
9 Ющишин І. Колективізм чи індивідуалізм: Завваги до громадівських інстинктів нашого народу. Шлях виховання і навчання. 1930. Ч. 5. С. 130.

${ }_{11}^{10}$ Макарушка О. Наука вихованя : [підручник для шкіл і родин]. Львів : Накладом автора, 1922. С. 3.

${ }_{11}^{11}$ Куцій М. Естетичне виховання. Шлях навчання і виховання. 1928. Ч. 1. С. 23.

12 Терлецький Г. Виховне навчання. Львів, 1939. 19 с.
} 
national tradition, an independent, ready-for-life individual who can draw from the past, look wisely at the present and have faith in the future, with the desire for active cooperation in building a better Tomorrow"13.

The continuation of these scientific studies was to substantiate the basic principles of national education. In this context, Yaroslav Kuzmiv constructed a reasoning on the basis of a value approach and turned to the field of pedagogy of culture. By the term "culture", he meant not so much the cultural values which are being produced, but rather the spiritual process which takes place on their basis (customs, morals, religion, art, science, language, economic values, literature, etc.). Therefore, according to Kuzmiv, education is the introduction of the child into the world of cultural values (understanding them as a continuous process) "which are never complete", and therefore the task of education can never be fully achieved. In view of this, the author has justified several statements:

1) education is a continuous realization of cultural values among the youth, who must not only be their bearers, but also creators;

2) since no culture exists abstractly, outside the nation, "every true and complete education cannot be national";

3) the tasks of national education are: a) awakening and continuous strengthening of national consciousness; b) uniting all layers of the nation around common national ideals; c) awakening and development of the genius of the people in the field of thought and joint efforts; d) the development of good national traits and the elimination or reduction of undesirable ones.

In view of the above, Yaroslav Kuzmiv substantiated the ideal of education, a new type of person, "equipped with the most desirable, useful (physical and mental) traits, an individual who feeds on the achievements of past generations and is conscious of their spiritual connection with them, a person who multiplies and deepens national culture and brings its values into the cultural treasury of the world through their creative efforts..."14.

\footnotetext{
${ }^{13}$ Велигорський І. Українознавство. Украйнська школа. 1934. Ч. 19. С. 2-15.

${ }^{14}$ Кузьмів Я. Напрямні національного виховання. Периий Украӥнський Педагогічний Конгрес у Львові (1935). Львів, 1938. С. 191-194.
} 
The necessity of forming a generation that is conscious of the purpose of their nation, capable of building a state and educating the "state-building youth", was supplemented by Vasyl Pachovskyi. The educator specified the spiritual values which should be instilled in the young generation "so that they are ready for the greatest sacrifices for them". In particular, he drew attention to national self-respect, personal dignity and pride in belonging to the Ukrainian nation, which is an equal culture with that of other state peoples. He noted that blatant rudeness among pupils should be replaced with a sense of dignity and honor. There should be obedience to the state power instead of betrayal and discipline instead of political prostitution, submission to the leadership authority instead of peskiness and subordination to the organized church instead of religious sectarianism, coordination of state necessity instead of political anarchism and systematic work on the transformation of the nation into "a disciplined material for state building" instead of explosive mysticism ${ }^{15}$.

According to Stepan Rudnytskyi, an important value of national education is the love of the motherland, which means not only love for one's home, native village, town or a neighborhood, but love for all the land and space "where people speak their mother tongue, abide by their native customs, live with their memories of the past and cherish their hopes for the future!.. As Ukrainians, we need to firmly love all that is good and beautiful about Ukraine and to eschew everything that is evil and bad, and to work hard to keep it out of Ukraine"16. Involvement of regional values in the upbringing should also help to shape such a personality. After all, according to Stepan Malaniuk, they have grown into the psyche of everyone who lives in a particular locality and has a great incentive force for social work. That is why it is important to study the local values of your people and to base creative work on them for the economic and cultural upbringing of the nation ${ }^{17}$.

\footnotetext{
15 Пачовський В. Українознавство у вихованні молоді. Периий Украйнський Педагогічний Конгрес у Львові (1935). Львів, 1938. С. 89-113.

${ }_{17}^{16}$ Рудницький С. Україна наш рідний край: Коротка географія. Львів, 1921. С. 5-8.

17 Маланюк С. Місцеві цінності в скарбниці національного виховання Методика і шкільна практика: Додаток до часопису «Шлях виховання й навчання». 1933. С. 203-211.
} 
According to Western educators, the involvement of children and youth in civic values is an extremely important task. In times of liberation (1918), Ivan Boberskyi chose the following words as an epigraph for his diary: "A good state is the pinnacle of human creativity on earth. Each member of the state system must fulfill their duty flawlessly, like the wheel in the clock"18. In order to do this, they must absorb a number of values of civic life, as emphasized by Yaroslav Kuzmiv, Myroslav Semchyshyn and Ivan Yushchyshyn. A school which would provide not only valuable education but also bring up active, conscious, creative, useful, able-bodied and productive citizens was considered by educators an important institution of civic education ${ }^{19}$.

Religious and moral education was also declared an important task of educational institutions. The resolutions and regulations of the First Ukrainian Pedagogical Congress stated that it was only appropriate to have a system of upbringing based on Christian faith, science, and morality. The same document defines the importance of the implementation of national, social, artistic, spiritual, hygienic and physical education which gives the opportunity to fully prepare Ukrainian youth for the realization of the highest ideal of the nation, the effective creative participation in the development of native spiritual and material culture, as well as participation in universal human culture as a whole ${ }^{20}$.

The Galician educators paid considerable attention to aesthetic education. In particular, Matviy Kutsiy noted that "the modern school also takes thorough care of aesthetic education. To educate aesthetically is to awaken the feelings of beauty, the ability to feel and touch it, and finally to observe the beauty in nature and art" ${ }^{\prime 21}$.

Peter Bilaniuk considered the character (and not the intellect, as it was in the era of the development of positivism) to be the ideal of the post-war

\footnotetext{
${ }^{18}$ ЦДАВО України. Ф. 4379. Оп. 1. Спр. 21. Щоденник Боберського І. за 1918-1919 pp., 28 серпня 1944 р. Арк. 2.

19 Кузьмів Я. Шкільні характеристики учнів. Шлях виховання й навчання. 1930. Ч. 7. С. 204-210; Семчишин М. Українознавство та його роля в школі. Учительське Слово. 1939. Ч. 1-2. С. 3-4; Ющишин I.M. Нові наукові програми в народних школах. Методика і шкільна практика: Додаток до часопису «Шлях виховання й навчання». 1933. С. 133-136.

20 Резолюції і постанови Першого Українського Педагогічного Конгресу. Периий Український Педагогічний Конгрес у Львові (1935). Львів, 1938. С. 236-249.

${ }^{21}$ Куцій М. Естетичне виховання. Шлях навчання і виховання. 1928. Ч. 1. С. 19.
} 
school $^{22}$. Petro Parashchyn agreed with him, as he saw the greatest value of every nation in people who possess a strong character, a solid foundation on which "one can safely build a better future not only for individual units but also for the whole nation" 23 .

The school of post-war Europe was given the task of creating a new type of a person capable of living in a democratic society. Educators in Eastern Galicia were familiar with the views of foreign scholars and were aware of their relevance and importance in the education of young Galicians. In this regard, Ivan Yushchyshyn wrote: "Through the efforts of the world's most popular theorists and practitioners of education, contemporary pedagogy has put one indispensable thesis at the head of educational ideals as a condition for rational human development, and that is activity and creativity! Taking this motto as a basis of their activity, modern educators have strongly criticized the old school of passivism and verbalism, the idea of which was opposite to that of school of work where pupils are given complete freedom to express their activity and creativity" 24 . Similar views were shared by Hryhoriy Terletskyi, who believed that in order to effectively assimilate values, the pupil must be active, independent and creative ${ }^{25}$. Ostap Makarushka saw the purpose of education in the creation of a noble character guided by moral principles and aware of their belonging to the community. "A person of such a noble nature will live not only for their own well-being, but for the well-being of the ones surrounding them. Therefore, they will conscientiously and justly fulfill their duties towards their loved ones." In this case, the teacher considered independence as an important feature that must be formed in the pupil ${ }^{26}$.

The physical and valeological upbringing of the younger generation was no less important in the interwar period. Recognizing health as the greatest treasure of the nation, Olha Makarushka-Terpyliakova

\footnotetext{
${ }^{22}$ Біланюк П. Не лише вчимо, але й виховуємо. Рідна школа. 1936. Ч. 20. С. 293-296.

${ }^{23}$ Паращин П. Дайте дітям характер. Рідна школа. 1936. Ч. 4. С. 75.

${ }^{24}$ Ющишин І. Драматизація в школі. Шлях виховання й навчання. 1927. № 9. С. 10.

25 Терлецький Г. Виховне навчання. Львів, 1939. 19 с.

${ }^{26}$ Макарушка О. Наука вихованя : [підручник для шкіл і родин]. Львів : Накладом автора, 1922. С. 4.
} 
acknowledged a great need to educate citizens about the understanding of "the weight of good health" in the essay "The Importance of Public Hygiene" 27 . This task was emphasized both in educational campaigns and in physical education of children and youth. Educators and public figures in Galicia were well aware of its importance for the comprehensive development of the individual, in particular for national and educational character. Taras Franko was convinced that only exercise can bring up a new and strong generation, because it helps youth to form "organizational sense, calls for division of labor, responsibility for the embraced task, conscientiousness and accuracy, mastering the right effort and belief in own forces... It maintains harmony between mind and body, produces courage, willpower and speed of orientation" ${ }^{\text {"28 }}$.

However, educators have warned that educational work is often leveled by other factors, including the media. Extremely relevant are the words of Myron Fedusevych, written in 1939, about how difficult it is to educate the younger generation in a situation where the school seeks to instill in them such virtues as altruism and obedience while the real life gives examples of the triumph of the fist, cunning and power ${ }^{29}$.

According to Galician educators, namely Ivan Velyhorskyi, Yaroslav Kuzmiv and Myroslav Semchyshyn, in such a contradictory situation the goal of education can be fully realized only by the efforts of the school. According to Ivan Yushchyshyn, the school achieves its goals through its basic ideological direction, the highest spirit and the teaching of different subjects ${ }^{30}$. Thus, Ivan Velyhorskyi wrote: "The road to this goal is a school of work, an active school that teaches young people not only with words, but also gives them a meaning and teaches them to create the meaning of their own lives for themselves." Furthermore, the author elaborated on the content of Ukrainian studies education which, in his opinion, should

\footnotetext{
${ }^{27}$ ЦДІАЛ. Ф. 319. Оп. 1. Спр. 104. Матеріали про діяльність гігієнічної секції товариства, програми курсів, доповіді, листи та ін., 1939 р. Арк. 19.

${ }_{28}$ Франко Т. Історія та теорія руханки. Коломия - Львів : накладом Сокола-Батька, 1923. С. 119.

${ }^{29}$ Федусевич М. За нові українські читанки для гімназій і ліцеїв. Украйнська Школа. 1939. Ч. 1. № 6. С. $30-46$.

${ }^{30}$ Ющишин I. Середовище й програми навчання в народніх школах. Методика і шкільна практика: додаток до часопису «Шлях виховання й навчання». 1933. С. 159-182.
} 
include native language, literature, language history, folklore, ethnology, ethnography, archeology, folk poetry and art (music, painting, architecture), national law, beliefs, paleography, etc. ${ }^{31}$. Yaroslav Kuzmiv also included the modern life of the nation under conditions created by nature (partly by human labor and other influences) in the content of education $^{32}$. Having determined the didactic and educational purpose of Ukrainian studies, Myroslav Semchyshyn noted that mastering the basics of native culture by youth contributes to the formation of respect and love for everything that is native and familiar. When getting acquainted with their native language, the youth learn to appreciate it and to honor it "as the language of their national group". Knowledge of native literature enables pupils to learn about the lives and deeds of past generations and to find examples worthy of imitation. Geography makes it possible to cultivate love for the native land and its riches, and "to mentally connect with it as the foremother of the nation." History brings the youth closer to the past generations and reveals the glorious deeds and exploits of their ancestors ${ }^{33}$.

Educators Yaroslav Kuzmiv and Vasyl Pachovskyi also outlined the requirements that a school as an educational institution must meet: 1) to provide a comprehensive choice of national cultural values; 2) the whole life of the school must be imbued with the national spirit; 3) methods of education and training in schools should correspond to the psychological characteristics of children and the needs of the nation; 4) teachers should be of the same nationality as the students ${ }^{34}$ and be the bearers of national values and mental traits. They are obliged to always remember that they fulfill the mission of the apostles, because, in creating new people, they form a family, city, citizenship, nation through their pupils ${ }^{35}$.

The views of the brothers Bohdan and Kornylo Zaklynskyi are a striking example of Western Ukrainian pedagogical thought. Having made

\footnotetext{
${ }_{31}^{31}$ Велигорський І. Українознавство. Українська школа. 1934. Ч. 19. С. 2-15.

32 Кузьмів Я. Напрямні національного виховання. Перший Украйнський Педагогічний Конгрес у Львові (1935). Львів, 1938. С. 191-194.

${ }_{33}$ Семчишин М. Українознавство та його роля в школі. Учительське Слово. 1939. Ч. 1-2. С. 3-4.

${ }_{34}^{34}$ Кузьмів Я. Напрямні національного виховання. Перший Украйнський Педагогічний Конгрес у Львові (1935). Львів, 1938. С. 191-194.

35 Пачовський В. Українознавство у вихованні молоді. Перший Украӥнський Педагогічний Конгрес у Львові (1935). Львів, 1938. С. 113.
} 
a major contribution not only to folkloristics, ethnography, literary studies and literature, but also to pedagogy, they were highly educated, erudite and had a wide range of interests. The Zaklynskyi brothers have proven themselves to be talented teachers and were the authors of pedagogical works that have not lost their relevance today.

Like the other Zaklynskyi brothers (there were eight of them), they were heavily influenced by family upbringing and the atmosphere of a family hearth. Their father Roman Zaklynskyi (1832-1931) was a writer, literary critic, educator, cultural and educational figure. Bohdan and Kornylo Zaklynskyi followed in their father's footsteps. Having been educated at the Stanislav Gymnasium and Teacher's Seminary, Bohdan Zaklynskyi (1886-1946) worked in the section of the Ukrainian National Cultural Council in Vienna, was a teacher in public schools of Transcarpathian Ukraine (which at the time was a part of the Czechoslovak Republic) and private Ukrainian educational institutions of Galicia. In particular, he taught in such settlements of Transcarpathia as Turi Remety, Dubrynychi, Zarichiv, Velykyi Bychkiv and Yasinya. Upon returning to Galicia, he worked in Zolochiv, Lviv and the village of Medvedivka in Ternopil region.

Bohdan Zaklynskyi was an author of more than a hundred scientific articles, brochures, textbooks and handbooks. Among the most popular of them are The Ukrainian Primer (1916), A Primer for Courteous Children (1917), National Education (1927), An Active School (1927), and Education of Leaders (1928). The titles of these works speak for themselves. A prominent place in the upbringing of the younger generation was assigned by the educator to the formation of nationally conscious, active personality who would be able to lead others. "In times of great changes in our national life, the greatest task of education is to train the young Ukrainian generation to be able to serve the liberation and reconstruction of their native land"36. Only the younger generation is

\footnotetext{
${ }^{36}$ ЦДАВО України. Ф. 3896. Оп. 1. Спр. 3. Рукописи статей «Коломийковський віночок», «Йосип Пешик», доповіді «Дитяча книжка», прочитаної на сходинах вчительсько-педагогічного гуртка міської школи в Рахові 1925 р. тощо. Арк. 26.
} 
capable of fulfilling the task of Ukrainian national construction, and therefore, of course, its upbringing is the most important thing and a necessity.

Bohdan Zaklynskyi was convinced that "the future of our nation lies in the good and national upbringing of children"37. At the same time, he considered it advisable to take foreign experience (of which he was well aware) into consideration. As an example, he cited the particularities of the practice of educating a citizen in Western Europe. "And now the West is turning to the education that is set to awaken the great impulses of admiration and readiness for personal sacrifices which have been sleeping inside the human soul. They are looking for new roads in education to fight the domination of individual will with personal pretense and to make others cherish the foundations of collective will",38.

An example of sacrifice for the sake of own nation is found in the biography of Bohdan Zaklynskyi himself. At the beginning of World War I, he and his five brothers joined the Legion of Ukrainian Sich Riflemen. Therefore, the following lines from his work "What Should Every Ukrainian Know?"39 can be considered the motto of the author himself: "Giving your life for your own nation is the highest merit a person can obtain...". That is why "the greatest honor belongs to these heroes!". Apparently, due to the life circumstances of Bohdan Zaklynskyi himself, the Western European experience was close and clear to him.

Therefore, it becomes clear how important for the scientist was the formation of a nationally conscious citizen, a patriot. He pointed out that "patriotism is a genuine love for your own nation and your native land. And the patriot is an individual who tries to help their nation and works for its well-being with all their strength" ${ }^{\prime 0}$. Thus, the love for the Motherland

\footnotetext{
37 Заклинський Б. Що треба знати кождому українцеви? Відень : накладом «Союза визволення України», у друкарні ад. Гольцгавзена у Відні, 1915. С. 30.

${ }^{38}$ ЦДАВО України. Ф. 3896. Оп. 1. Спр. 3. Рукописи статей «Коломийковський віночок», «Йосип Пешик», доповіді «Дитяча книжка», прочитаної на сходинах вчительсько-педагогічного гуртка міської школи в Рахові 1925 р. тощо. Арк. 28.

39 Заклинський Б. Що треба знати кождому українцеви? Відень : накладом «Союза визволення України», у друкарні ад. Гольцгавзена у Відні, 1915. 39 с.

40 Заклинський Б. Що треба знати кождому українцеви? Відень : накладом «Союза визволення України», у друкарні ад. Гольцгавзена у Відні, 1915. С. 26.
} 
must be deedful and manifested not in unfounded phrases, but in constant work for the sake of its good and the good of all its citizens.

The educator organized reading rooms of Prosvita, centers of Native School and Plast associations. According to him, Plast was extremely important in the education of the younger generation, because it was able to bring up active, deedful patriots of their homeland. Bohdan Zaklynskyi described the task of educating children and youth as follows: "Education should be directed primarily towards mobility (activity). Ukrainian youth nowadays must be creative, productive and do great work." Undoubtedly, such a task was resulted by the problems of building a Ukrainian nation and improving all spheres of its life. "All areas of life are in need of new, creative work, so we need to bring up people for whom continuous work is a joy. And there is a lot of it to be done in the cultural, economic and political fields". Recognizing the great educational value of family and public school and believing that "family is the foundation of the nation" 41 , the educator nevertheless thought that Plast played a significant role in the upbringing of such people: "only Plast can prepare capable and mobile people" ${ }^{42}$.

According to Bohdan Zaklynskyi, the realization of these tasks must be done primarily through the cultivation of will, intelligence and morality. "In order to get the kind of mobile people we desperately need, we must pay attention to the cultivation of freedom. This is the most important task of national education" 43 . The development of intelligence and morality is necessary for a young person to set a goal and to pursue it morally.

The effectiveness of Plast's organizing activity is evidenced by the fact that its ideas are firmly rooted in the souls of its students. In particular, the personal fund of the educator, which is kept in the Central State Archive of Supreme Bodies of Power and Government of Ukraine,

\footnotetext{
41 Заклинський Б. Що треба знати кождому українцеви? Відень : накладом «Союза визволення України», у друкарні ад. Гольцгавзена у Відні, 1915. С. 30.

${ }^{42}$ ЦДАВО України. Ф. 3896. Оп. 1. Спр. 3. Рукописи статей «Коломийковський віночок», «Йосип Пешик», доповіді «Дитяча книжка», прочитаної на сходинах вчительсько-педагогічного гуртка міської школи в Рахові 1925 р. тощо. Арк. 47.

43 ЦДАВО України. Ф. 3896. Оп. 1. Спр. 3. Рукописи статей «Коломийковський віночок», «Йосип Пешик», доповіді «Дитяча книжка», прочитаної на сходинах вчительсько-педагогічного гуртка міської школи в Рахові 1925 р. тощо. Арк. 47.
} 
contains letters from former students ${ }^{44}$ sent to Bohdan Zaklynskyi in Yasinya, where he was teaching at the time. Nearly all of them end with the plastonic cry of "SKOB" (Sylno, Krasno, Oberezhno, Bystro), which embodies both characteristic and the motto of the Plast member: strong in body and mind, beautiful in soul, careful in ideas and plans, fast in thought and deeds. It testifies to the importance and relevance of the ideas underlying the organization's activities to the pupils. This is also evidenced by the drawing of the Plast camp presented to the educator by the Plast members, as well as a poem that embodies the ideas he sought to convey to the pupils.

Bohdan Zaklynskyi considered a children's book to be one of the most important means of education. Speaking in 1925 at a meeting of a teacherpedagogical group of a local school in Rakhiv, the educator emphasized that "a children's book gives children and, through them, the whole nation a spiritual development, because it brings up a new generation that is aware of its nationality. So we can see that the future of the people lies in books." Therefore, the speaker tried to outline the values that should be embodied in children's literature: "Let's put beauty, good and truth in our children's books so they could learn to see and understand it" 45 .

Perhaps the best confirmation of the effectiveness of pedagogical activity for every educator is the gratitude of the former pupils and their awareness of the great work that the educator does every day. Bohdan Zaklynskyi had grateful pupils with whom he kept in touch even after finishing working with them. Among the correspondence stored in Bohdan Zaklinsky's fund in the Central State Archive of Supreme Bodies of Power and Government of Ukraine, extremely eloquent is the letter by Gloria, written to the teacher on May 14, 1927 in Yasinya. In the letter we can come across the following lines: "This perseverance and love that is embedded in our peasant hearts comes from our kind tutors who were not

\footnotetext{
44 ЦДАВО України. Ф. 3896. Оп. 1. Спр. 16. Листи від учнів, 25 жовтня 1925 р. - 12 червня 1927 р., 35 арк.

ЦДАВО України. Ф. 3896. Оп. 1. Спр. 3. Рукописи статей «Коломийковський віночок», «Йосип Пешик», доповіді «Дитяча книжка», прочитаної на сходинах вчительсько-педагогічного гуртка міської школи в Рахові 1925 р. тощо. Арк. 1.
} 
ashamed of the poor peasants and enlightened them. To whom should we be grateful? Who tried to enlighten us? You, Professor. You were the one who was not ashamed of us, and we know and remember it well. It was you and this was your job. And so, our father, Professor, as soon as I see your words somewhere, great dedication and love for my people immediately begins to shine through me" 46 .

Bohdan Zaklynskyi's younger brother Kornylo (1889-1966) received a thorough education. He studied at the Stanislav Gymnasium and later continued his studies at the University of Vienna, Chernivtsi and Lviv, graduating from the Faculty of Philosophy in 1915. Zaklynskyi worked as a teacher in the village of Vashkivtsi in Bukovyna, and from 1920 to 1938 he was a professor at the Berehove Ukrainian Private Gymnasium. Like his older brother, he was an activist of Prosvita and the organizer of the Plast movement.

Kornylo Zaklynskyi's views on the upbringing were in line with the ideas of Bohdan Zaklynskyi. He believed that the leading role in the upbringing of the younger generationwas played by the formation of the national consciousness of Ukrainians, and that the life of a nation lies in meeting its own national, cultural, economic and political needs. National and cultural aspirations should be implemented through the introduction of national studies, school and native language, as well as rights and laws that correspond to the customs and attitudes of the people. This is the only way to ensure the free development of the nation and to create a native culture, science and $\operatorname{art}^{47}$. For this purpose it is necessary to educate conscious Ukrainians and good citizens of their country. According to Kornylo Zaklynskyi, this can only be done in the home school using the native language.

The article "Observations on Practical Classes", which is stored in Kornylo Zaklynskyi's fund in the Central State Archive of Supreme Bodies of Power and Government of Ukraine, is devoted to the seemingly narrow

\footnotetext{
${ }^{46}$ ЦДАВО України. Ф. 3896. Оп. 1. Спр. 16. Листи від учнів, 25 жовтня 1925 р. - 12 червня 1927 p. Арк. 24.

${ }^{47}$ ЦДАВО України. Ф. 4388. Оп. 1. Спр. 1. Статті «Наші політичні, культурні та економічні домагання в Росії» та «Що треба знати кожному українцю», 1915 р. Арк. 2-7.
} 
methodical problem of organizing manual work. However, it expresses the views of the author on the upbringing of the younger generation, which are concerned with the formation of a well-rounded personality, since they cover moral, physical, intellectual, aesthetic and labor education. According to the educator, one of the most important means of education is work: "The best teacher is work, personal ability, amateur activity, this principle of an active school. All students should be given the opportunity to develop and prove themselves for the good of the nation" 48 . Undoubtedly, these words have not lost their relevance today, as well as the educational tasks which Kornylo Zaklynskyi puts before the school and practical classes in particular.

The educator considered creative mental exertion to be the most important task of manual work for children, as it will allow them to accomplish a variety of other tasks, namely:

"We must imbue children with:

1) Conscious attitude to each and every working process.

2) Respect for all creative work, regardless of its content.

3) Development of the will to creativity and ability to translate their ideas into a specific practical form.

4) The development of self-awareness as a necessary useful employee of the children's collective, citizenship, nation, state.

5) Development of abilities and individual traits"

The educator called for the realization of these tasks through the implementation of mental, moral, physical, aesthetic and labor education. At the same time, he is convinced that manual work helps to harmonize all the directions of education. After all, "the development of aesthetic taste, symmetry, systematics, precision, independence in work, love of work is all the merit of manual work. It subconsciously raises the moral value of the child. "However, these are not the only educational opportunities of manual work. While performing various practical tasks, children receive "the opportunity for specific thinking", as exercises "occupy them practically". "While working, children carefully observe everything, think about the details and strengthen their notions... During conversations at manual labor,

\footnotetext{
${ }_{48}^{48}$ ЦДАВО України. Ф. 4388. Оп. 1. Спр. 3. Стаття «Завваги до практичних занять», б/д. Арк. 6.

${ }^{49}$ ЦДАВО України. Ф. 4388. Оп. 1. Спр. 3. Стаття «Завваги до практичних занять», б/д. Арк. 2.
} 
children are more daring while speaking about details, they come to more accurate conclusions, and it helps to master their native language"

In order to provide comprehensive development for ech individual, it is important for the educator to be ready for this kind of work. "The work of educators is not very intensive here, though they only play the role of a friend and advisor to the child. He then uses all the moments that develop the amount of knowledge in the area of each subject, leaving the children freedom and initiative in the choice of activities, because it develops independence" ${ }^{, 51}$.

The educator's ideas certainly sound very modern. Today, the issues of pedagogy of cooperation, the need to provide every child with opportunities for free development, activity and initiative are as relevant as ever. Therefore, the appeal to the heritage of past Ukrainian educators may outline possible ways of solving the current problems of modern pedagogy and practice of education.

Therefore, Kornylo and Bohdan Zaklynskyi's views on the upbringing of the younger generation remain relevant to this day and can serve as a guide for modern educators to improve the national education system. The idea of national upbringing and transference of human values that form the basis of moral education to the younger generation is the cross-cutting theme of all the pedagogical works of educators. Another important aspect of their pedagogical views is the idea of forming an independent creative personality needed by the modern world. In our opinion, this is the main reason why the heritage of Ukrainian educators needs to be deeply researched and adapted to modern realities.

\section{CONCLUSIONS}

Having analyzed the views on the educational ideal of Ukrainian and Polish educators who worked in Western Ukraine during the interwar period, we can conclude that they were developed mostly within the framework of pedagogy of national and civic education, and were based on national, civic and Christian values.

\footnotetext{
${ }_{50}^{50}$ ЦДАВО України. Ф. 4388. Оп. 1. Спр. 3. Стаття «Завваги до практичних занять», б/д. Арк. 1.

${ }^{51}$ ЦДАВО України. Ф. 4388. Оп. 1. Спр. З. Стаття «Завваги до практичних занять», б/д. Арк. 1.
} 
The analysis of the educational values of the interwar period showed their dependence on the stateless position of Ukraine and the aspirations of the Ukrainians for independence, as well as on the development of a large number of directions and trends which characterize the pedagogy of the late nineteenth and early twentieth centuries.

\section{SUMMARY}

The article analyzes the requirements for the educational ideal which have been substantiated in pedagogical works of Western Ukraine during the interwar period. The characteristic of the educational ideal, substantiated by Polish educators, as well as the approaches to the substantiation of the educational ideal by Ukrainian educators, are presented. The political and economic preconditions for crystallization of the educational ideal are characterized. It has been proved that the views on the educational ideal of Ukrainian and Polish educators who worked in Western Ukraine during the interwar period were developed mostly within the framework of pedagogy of national and civic education. They were based on national, civic and Christian values.

The analysis of the educational values of the interwar period showed their dependence on the stateless position of Ukraine and the aspirations of the Ukrainians for independence, as well as on the development of a large number of directions and trends which characterize the pedagogy of the late nineteenth and early twentieth centuries.

\section{REFERENCES}

1. Біланюк П. Не лише вчимо, але й виховуємо. Рідна школа. 1936. Ч. 20. С. 293-296.

2. Велигорський I. Українознавство. Украӥнська школа. 1934. Ч. 19. С. $2-15$.

3. Заклинський Б. Що треба знати кождому українцеви? Відень : накладом «Союза визволення України», у друкарні ад. Гольцгавзена у Відні, 1915. 39 с. 
4. Кузьмів Я. Напрямні національного виховання. Перший Украйнський Педагогічний Конгрес у Львові (1935). Львів, 1938. C. 191-194.

5. Кузьмів Я. Шкільні характеристики учнів. Шлях виховання й навчання. 1930. Ч. 7. С. 204-210.

6. Куцій М. Естетичне виховання. Шлях навчання $i$ виховання. 1928. Ч. 1. С. 19-23.

7. Макарушка О. Наука вихованя : [підручник для шкіл і родин]. Львів : Накладом автора, 1922. 152 с.

8. Маланюк С. Місцеві цінності в скарбниці національного виховання Методика $i$ шкільна практика: Додаток до часопису «Шлях виховання й навчання». 1933. С. 203-211.

9. Паращин П. Дайте дітям характер. Рідна школа. 1936. Ч. 4. C. $72-75$.

10. Пачовський В. Українознавство у вихованні молоді. Перший Украйнський Педагогічний Конгрес у Львові (1935). Львів, 1938. C. 89-113.

11. Резолюції і постанови Першого Українського Педагогічного Конгресу. Перший Украӥнський Педагогічний Конгрес у Львові (1935). Львів, 1938. С. 236-249.

12. Рудницький С. Україна наш рідний край: Коротка географія. Львів, 1921. 128 с.

13. Семчишин М. Українознавство та його роля в школі. Учительське Слово. 1939. Ч. 1-2. С. 3-4.

14. Терлецький Г. Виховне навчання. Львів, 1939. 19 с.

15. Ушинський К. Про народність у громадському вихованні. Вибрані педагогічні твори : у 2-х m. К. : Радянська школа, 1983. Т. 1. C. 43-104.

16. Феделешъ В.И. Учебникъ исторіи Подкарпатской Руси отъ найдавнЂйшихъ временъ до днешнихъ дней и Чехословакіи до XIV. вЂека. Мукачево : Типографія «Карпатія», 1922. 50 с.

17. Федусевич М. За нові українські читанки для гімназій і ліцеїв. Українська Школа. 1939. Ч. 1. № 6. С. 30-46. 
18. Франко Т. Історія та теорія руханки. Коломия - Львів : накладом Сокола-Батька, 1923. 200 с.

19. ЦДАВО України. Ф. 4388. Оп. 1. Спр. 1. Статті «Наші політичні, культурні та економічні домагання в Росії» та «Що треба знати кожному українцю», 1915 р., арк. 2-7.

20. ЦДАВО України. Ф. 4388. Оп. 1. Спр. 3. Стаття «Завваги до практичних занять», б/д, 11 арк.

21. ЦДАВО України. Ф. 3896. Оп. 1. Спр. 16. Листи від учнів, 25 жовтня 1925 р. - 12 червня 1927 р., 35 арк.

22. ЦДАВО України. Ф. 3896. Оп. 1. Спр. 3. Рукописи статей «Коломийковський віночок», «Йосип Пешик», доповіді «Дитяча книжка», прочитаної на сходинах вчительсько-педагогічного гуртка міської школи в Рахові 1925 р. тощо, 266 арк.

23. ЦДАВО України. Ф. 4379. Оп. 1. Спр. 21. Щоденник Боберського I. за 1918 - 1919 рр., 28 серпня 1944 р., 183 арк.

24. ЦДІАЛ. Ф. 319. Оп. 1. Спр. 104. Матеріали про діяльність гігієнічної секції товариства, програми курсів, доповіді, листи та ін., 1939 р., 47 арк.

25. Ющишин I.M. Нові наукові програми в народних школах. Методика $i$ шкільна практика: Додаток до часопису «Шлях виховання й навчання». 1933. С. 133-136.

26. Ющишин I. Колективізм чи індивідуалізм: Завваги до громадівських інстинктів нашого народу. Шлях виховання і навчання. 1930. Ч. 5. С. 129-133.

27. Ющишин I. Драматизація в школі. Шлях виховання $\check{u}$ навчання. 1927. № 9. С. 4-12.

28. Ющишин I. Середовище й програми навчання в народніх школах. Методика і шкільна практика: додаток до часопису “Шлях виховання й навчання". 1933. С. 159-182.

29. Ярема Я. Нова фаза в розвитку європейської школи. Украӥнська Школа. 1934. Річник ХІХ. С. 3-11.

30. Łempicki S. O ideał wychowania w Polsce (Wyniki ankiety). Lwów, 1929. 22 s. 
31. Pannenkowa I. Myśli o wychowaniu narodowem. Lwów : Nakł. "Polskiego T-wa pedagogicznego", 1918.98 s.

32. Pannenkowa I. Nasze zadania wychowawcze. Warszawa, $1929.28 \mathrm{~s}$.

\section{Information about the author:} Nevmerzhytska $O$.

Doctor of Pedagogical Sciences, Associate Professor, Professor at the General Pedagogy and Preschool Education Department,

Drohobych Ivan Franko State Pedagogical University 24, Ivan Franko str., Drohobych, 82100, Ukraine 